\title{
周術期におけるナロキソン塩酸塩およびオピオイドの 適正使用推進に対する取り組みの評価
}

\author{
新井聡子 ${ }^{* 1}$, 小井土啓一 ${ }^{1}$, 深田英嗣 ${ }^{1}$, 赤木 徹 $^{1}$, 岩瀬治雄 ${ }^{1}$, 佐藤哲文 ${ }^{2}$, 寺門浩之 ${ }^{1}$ \\ 国立がん研究センター中央病院 薬剂部 ${ }^{1}$, 国立がん研究センター中央病院 麻酔・集中治療科 ${ }^{2}$
}

\section{Evaluation of Implementation for Promotion of Legal Use of Opioids and Naloxone in the Perioperative Period}

\author{
Satoko Arai ${ }^{* 1}$, Keiichi Koido', Eiji Fukada', Toru Akagi', \\ Haruo Iwase ${ }^{1}$, Tetsufumi Sato ${ }^{2}$ and Hiroyuki Terakado ${ }^{1}$ \\ Department of Pharmacy, National Cancer Center Hospital ${ }^{1}$, \\ Department of Anesthesia and Intensive Care, National Cancer Center Hospital ${ }^{2}$ \\ $\left[\begin{array}{l}\text { Received August 25, } 2017 \\ \text { Accepted February 19, } 2018\end{array}\right]$
}

\begin{abstract}
Although naloxone is used as an opioid antagonist, naloxone has a short half-life compared with opioids such as morphine and fentanyl. Therefore, there is a risk of developing a re-respiratory depression after administering an initial dose of naloxone. In our hospital operating room, after the first administration of naloxone, incident cases that resulted in the re-respiratory depression were reported. In order to standardize and minimize the use of naloxone during the perioperative period, our hospital developed a new protocol for the use of opioids and naloxone in the postanesthesia care unit. With the new protocol, naloxone administration was strictly managed by a clinical pharmacist to avoid arbitrary usage and to better monitor the incidence of adverse events. To minimize the need for opioid antagonists during the perioperative period, we also re-educated all anesthesiologists at our hospital on the proper use of opioids. We then retrospectively examined opioid usage, naloxone usage, the incidence of respiratory depression, and the incidence of adverse events before and after implementing the new protocol. The results indicate a significant reduction in the percentage of cases in which naloxone was used after the new protocol was implemented $(P=0.002)$. Naloxone was only used in one case, after the new protocol was implemented. Compared with the previous management method, there was a reduction in the usage of morphine after the new protocol was implemented. Based on the results of this study, the new protocol appears to effectively minimize the usage of naloxone during the perioperative period.
\end{abstract}

Key words — naloxone, opioid, pharmacist management, anesthesia, respiratory depression

\section{緒 言}

ナロキソン塩酸塩はオピオイド受容体に対し競 合的に作用する薬剤であり，オピオイド受容体は $\mu$ 受容体, $\kappa$ 受容体, $\delta$ 受容体の 3 種のサブタイ プに分類される. ${ }^{1)} \mu$ 受容体は中脳に存在する $\mu_{1}$ 受容体と脊髄後角に存在する $\mu_{2}$ 受容体の 2 つ タイプに分類され，オピオイドの作用として臨床 上問題となる呼吸抑制や鎮静作用は $\mu_{2}$ 受容体刺 激作用に由来すると言われている。 ${ }^{2}$
短時間作用性オピオイドであるレミフェンタニル 塩酸塩の登場により, オピオイド使用に伴う覚醒遅 延や呼吸抑制の頻度は減少している ${ }^{3,4)}$ が, 手術室 で抜管し一般病棟に帰室する場合には, 手術操作 による影響やほかの麻酔薬との相互作用, 患者側 のリスク因子 ${ }^{4)}$ によりオピオイド使用に伴う覚醒遅 延や呼吸抑制が出現することもある. ${ }^{1,5)}$ ナロキソン 塩酸塩は $\mu$ 受容体に対し高い親和性をもち, その 競合的特徵からオピオイドの副作用である呼吸抑 制に対し有効であり臨床で使用されている. ${ }^{6,7)}$

\footnotetext{
*テ104-0045 東京都中央区築地5-1-1
} 
一方，ナロキソン塩酸塩は肝臓でグルクロン酸 抱合を受け不活化されるため, ${ }^{1}$ そのほとんどは 初回通過で代謝され, 半減期は 19 分 $^{71}$ と短い. 長時間作用性のオピオイドに対して, ナロキソン 塩酸塩の投与は 1 回で済むとは限らず, $\left.{ }^{6}\right)$ ナロキ ソン塩酸塩初回拮抗後に再度生じ得る呼吸抑制に 対して注意が必要である. ${ }^{8}$

2013 年 5 月当院手術室に扔いて, ナロキソン塩 酸塩の初回投与量を投与した後に再呼吸抑制を生 じたインシデント事例が報告された。手術室にお いて，ナロキソン塩酸塩が適応または用法用量に おいて適切に使用されていない可能性が指摘され， 問題点として適応判断に対するチェック体制がな く, また担当麻酔医 1 人の判断で持ち出し可能な 管理方法が挙げられた。 そこでナロキソン塩酸塩 の管理体制の強化が必要と考え, 麻醉科および薬 剤部で, 適切なナロキソン塩酸塩の使用につなが るようなナロキソン塩酸塩の管理方法の変更につ いての協議を実施した. 公益社団法人日本麻醉科 学会の麻酔薬および麻酔関連薬使用ガイドライン (http://www.anesth.or.jp/guide/guideline-iyakuhinindex.html\#g02, 2017 年 12 月 9 日）のなかで提示 されている，「オピオイド拮抗薬を使用する際の 原則として，麻醉拮抗薬を使用する必要がないよ うな麻酔中のオピオイドの使用方法を心がける」, また,「オピオイド拮抗薬初回量の投与後, その 副作用を念頭に置き十分に患者の状態の観察を行 いながら状況に応じて維持量を投与する」などの 記載がある。これらの遵守を目的として, ナロキ ソン塩酸塩の管理方法をオピオイドによる呼吸抑 制などの副作用症状の有無や用法用量についての 確認を条件とした一定の使用制限を設けた常駐薬 剤師管理に変更（図 1）した。常駐薬剤師による ナロキソン塩酸塩の使用許可は，口頭によるもの とした。 さらに，オピオイド拮抗薬を使用する必 要がないような麻酔中のオピオイド使用の周知を 麻酔医に行った。

本研究では，管理方法の変更がナロキソン塩酸塩 の適正使用につながったか否かを評価するために, 管理方法変更前後でのナロキソン塩酸塩の使用状 況, 呼吸抑制発現率, オピオイドの使用状況，有害 事象発現状況を後方視的に調査したので報告する.

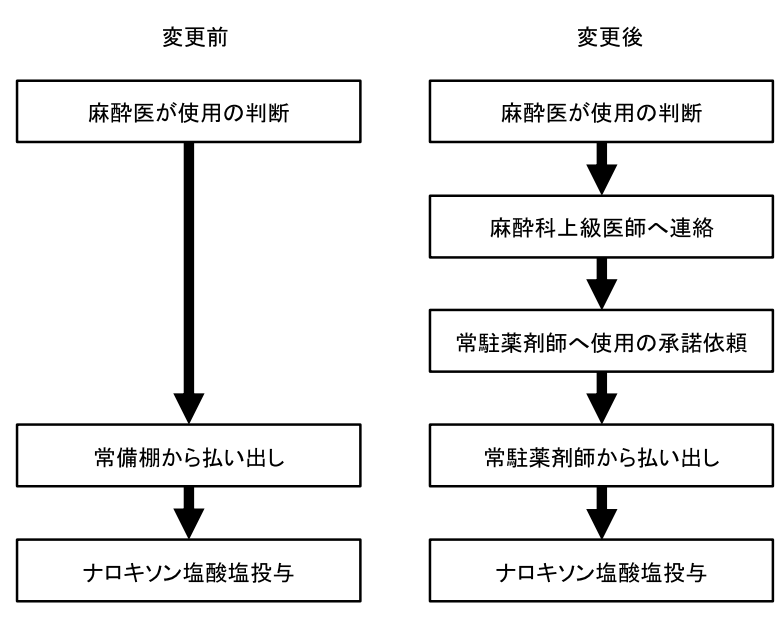

図 1 ナロキソン塩酸塩管理方法変更前後の投与まで の流れ

管理方法変更前は担当麻酔医の使用の判断にて常備棚より持ち 出しナロキソン塩酸塩が投与されていた。管理方法変更後は, 担当麻酔医が使用の判断後麻酔科上級医師へ連絡し, 麻酔科上 級医師より常駐薬剤師へ使用の承諾依頼があり, 常駐薬剂師よ り払い出しを行いナロキソン塩酸塩が投与される。使用承諾は オピオイドによる呼吸抑制などの副作用症状の有無や用法用量 の確認を条件とした。

\section{方 法}

\section{1. 研究デザイン}

後方視的調查によるコホート研究を行った.

\section{2. 対象}

2011 年 10 月〜 2014 年 1 月の期間に当院で麻酔 科関与手術を受けた症例を対象とした.このうち, 手術時間の記録が 0 分の症例は評価不能として除 外した.

管理方法変更前後で検討するため, 手術室のナ ロキソン塩酸塩の管理方法を変更した 2013 年 6 月を起算日として，管理方法変更前の 2011 年 10 月〜2013 年 5 月の症例を I 群, 変更後の 2013 年 6 月〜2014 年 1 月の症例を II 群とした.

\section{3. 調查項目}

本調査の情報抽出は, 診療録および周術期患者 情報システム（Fortec ORSYS ${ }^{\circledast ， フ ィ リ ッ フ ゚ ス ・ ~}$ ジャパン, 東京）により行った，対象期間より症例 を抽出し, 続いて性別, 年齢, 体重, 診療科, 病名, 術式, 硬膜外麻酔の有無, 麻酔時間, 手術時間, 使用薬剂 (モルヒネ塩酸塩, フェンタニルクエン酸 塩, レミフェンタニル塩酸塩, ファモチジン, メト 
クロプラミド, アセトアミノフェン, フルルビプロ フェン, フロセミド, ニカルジピン塩酸塩, ベラパ ミル塩酸塩), 退室時の項目 (術後疼痛, 嘔気, 血圧) などを抽出し後方視的に調查した。

また, ナロキソン塩酸塩の使用理由, ナロキソ ン塩酸塩初回使用後の再呼吸抑制発現状況につい て調査した。呼吸抑制の定義は, 術後呼吸数の著 名な低下（10 回/分以下）または医師の呼吸抑制発 現に関する医師記録とした，覚醒遅延は医師によ る覚醒遅延の診療録記載があったものと定義した.

ナロキソン塩酸塩の使用割合を下記式より算出 し，I 群と II 群で使用割合を比較した。

ナロキソン塩酸塩使用割合 $=\frac{(\text { 各群のナロキソン塩酸塩使用患者数 })}{(\text { 各群の全対象患者数 })}$

また，オピオイドの使用状況としてモルヒネ塩 酸塩, フェンタニルクェン酸塩, レミフェンタニ ル塩酸塩それぞれについて，使用症例数と使用量 を比較した，症例あたりの使用量は，以下の式に より算出した。
オピオイド使用量 $(\mu \mathrm{g} / \mathrm{min})$

$$
=\frac{(\text { 症例あたりのオピオイド使用量 }(\mu \mathrm{g}))}{(\text { 症例あたりの手術時間 }(\text { 分 }))}
$$

\section{4. 統計解析}

群間における割合の差の比較は， $\chi^{2}$ 検定を用い た．また， 2 群間における平均值の差の比較は，F 検定により等分散を確認したうえで，スチューデ ントの $t$ 検定を用いた．各検定における有意水準 は 5\%未満とした。統計解析は SPSS version 15.0, （日本アイ・ビー・エム(株), 東京）を用いた。

\section{5. 倫理規定}

本研究は,「疫学研究に関する倫理指針」を遵 守し, 当院の倫理審査の手続きに従い許可された ものである（承認番号：2014-156）.

\section{結果}

\section{I 群と I群の症例背景}

対象症例はI群 7,669 例, II 群 3,196 例であった。 症例背景を表 1 に示す。年齢中央值は I 群 62 （範

表 1 対象症例背景

\begin{tabular}{|c|c|c|c|c|}
\hline & & $\begin{array}{c}\text { I 群 } \\
(\mathrm{n}=7,669) \\
\end{array}$ & $\begin{array}{c}\text { II 群 } \\
(\mathrm{n}=3,196) \\
\end{array}$ & $P$ 值 \\
\hline \multirow{2}{*}{$\begin{array}{l}\text { 性別 } \\
\text { 年齢（歳） }\end{array}$} & \multirow{2}{*}{$\begin{array}{l}\text { 男性 /女性 } \\
\text { 中央值 [範囲] }\end{array}$} & $3,857 / 3,812$ & $1,620 / 1,576$ & 0.723 \\
\hline & & $62[0-97]$ & $63[0-93]$ & 0.767 \\
\hline 手術時間（分） & 平均 \pm 標準偏差 & $176.0 \pm 147.7$ & $174.9 \pm 144.8$ & 0.716 \\
\hline 麻酔時間（分） & 平均 \pm 標準偏差 & $226.0 \pm 162.2$ & $223.5 \pm 158.2$ & 0.453 \\
\hline 診療科内訳 & 呼吸器外科 & $1035(13.5 \%)$ & $432(13.5 \%)$ & 0.999 \\
\hline （症例数） & 乳腺外科 & $945 \quad(12.3 \%)$ & $396(12.4 \%)$ & 0.947 \\
\hline & 胃外科 & $781 \quad(10.2 \%)$ & $317(9.9 \%)$ & 0.702 \\
\hline & 大腸外科 & $774(10.1 \%)$ & $308(9.6 \%)$ & 0.492 \\
\hline & 泌尿器 - 後腹膜腫瘍科 & $582(7.6 \%)$ & $229(7.2 \%)$ & 0.468 \\
\hline & 眼腫瘍科 & $564(7.4 \%)$ & $227(7.1 \%)$ & 0.675 \\
\hline & 骨軟部腫瘍科 & $489(6.4 \%)$ & $213(6.7 \%)$ & 0.607 \\
\hline & 皮膚腫瘍科 & $433(5.6 \%)$ & $156(4.9 \%)$ & 0.119 \\
\hline & 肝胆膵外科 & $430 \quad(5.6 \%)$ & $189(5.9 \%)$ & 0.560 \\
\hline & 頭頸部腫瘍科 & $381(5.0 \%)$ & $198(6.2 \%)$ & 0.011 \\
\hline & 婦人腫瘍科 & $349(4.6 \%)$ & $145(4.5 \%)$ & 0.985 \\
\hline & 食道外科 & $234(3.1 \%)$ & $82(2.6 \%)$ & 0.190 \\
\hline & 脳脊髄腫瘍科 & $212(2.8 \%)$ & $86(2.7 \%)$ & 0.881 \\
\hline & 形成外科 & $206(2.7 \%)$ & $69(2.2 \%)$ & 0.127 \\
\hline & 放射線治療科 & $69(0.9 \%)$ & $35(1.1 \%)$ & 0.398 \\
\hline & 内視鏡科（消化管） & $62(0.8 \%)$ & $58(1.8 \%)$ & $<0.001$ \\
\hline & 内視鏡科（呼吸器） & $49 \quad(0.6 \%)$ & $13(0.4 \%)$ & 0.185 \\
\hline & 造血幹細胞移植科 & $34(0.4 \%)$ & $18 \quad(0.6 \%)$ & 0.501 \\
\hline & 小児腫瘍科 & $28(0.4 \%)$ & $14(0.4 \%)$ & 0.698 \\
\hline & その他 & $12(0.2 \%)$ & $11(0.3 \%)$ & 0.087 \\
\hline
\end{tabular}


囲 0-97）歳, II 群 63 歳（範囲 0-93）歳であった. 年齢, 性別は両群間に差はなかった。手術件数は 両群ともに呼吸器外科, 乳腺外科, 胃外科の順に 多かった。平均手術時間, 平均麻酔時間は両群間 に差はなかった。

\section{2. ナロキソン塩酸塩使用症例}

ナロキソン塩酸塩使用症例の背景を表 2 に示す. I 群のナロキソン塩酸塩使用症例は 31 例 (0.4\%), II 群のナロキソン塩酸塩使用症例は 1 例 （ $0.03 \% ） て ゙$ 管理方法変更後にナロキソン塩酸塩 使用割合は有意に減少した $(P=0.002)$ ． I 群症 例の背景は男性 16 例, 女性 15 例, 年齢中央值 68 歳（範囲 27-83）, 手術実施診療科は呼吸器外 科 11 例, 乳腺外科 2 例, 胃外科 4 例, 大腸外科 4 例などであった. II 群の症例背景は, 年齢 71 歳, 手術実施診療科は呼吸器外科だった。

\section{3. ナロキソン塩酸塩使用理由と用法用量}

ナロキソン塩酸塩の使用理由を表 2 に示す。 I
群の使用理由は不明が 19 例, 呼吸抑制が 8 例, 覚醒遅延が 4 例だった。 I 群でナロキソン塩酸塩 初回投与後に再度呼吸抑制が発現した症例は, 呼 吸抑制に対して使用された 2 例で， 1 例は人工呼 吸器管理, 1 例はナロキソン塩酸塩持続投与での 対応となった。

II 群の使用理由は呼吸抑制が 1 例だった. II 群 ではナロキソン塩酸塩初回投与後に再度呼吸抑制 が発現した症例はなかったＩI 群のナロキソン塩 酸塩を使用した 1 例はナロキソン塩酸塩使用後も 慎重なモニタリングを継続し詳細を診療録に記録 していた。

ナロキソン塩酸塩の平均使用量（平均 \pm 標準 偏差）は I 群 $0.19 \pm 0.16 \mathrm{mg}$, II 群 $0.1 \mathrm{mg}$ だった。 手術室におけるナロキソン塩酸塩投与方法は, I 群は単回投与 31 例（うち 1 例は手術室退室後, ナロキソン塩酸塩初回投与後に再度呼吸抑制を発 症しナロキソン塩酸塩持続投与となった), II 群 は単回投与 1 例で，複数回投与または持続投与は いなかった。

表 2 ナロキソン塩酸塩使用症例背景

\begin{tabular}{|c|c|c|c|}
\hline \multirow{2}{*}{\multicolumn{2}{|c|}{$\begin{array}{l}\text { ナロキソン塩酸塩使用症例数 } \\
\end{array}$}} & II群 & III 群 \\
\hline & & 31 & 1 \\
\hline 性別 & 男性／女性 & $16 / 15$ & $0 / 1$ \\
\hline 年齢（歳） & 中央值［範囲］ & $68[27-83]$ & 71 \\
\hline 手術時間（分） & 平均 \pm 標準偏差 & $199.1 \pm 120.7$ & 170 \\
\hline 麻酔時間（分） & 平均 \pm 標準偏差 & $279.7 \pm 134.3$ & 266 \\
\hline $\begin{array}{l}\text { 診療科内訳 } \\
\end{array}$ & 呼吸器外科 & $11(35.5 \%)$ & $1(100 \%)$ \\
\hline (症例数) & 乳腺外科 & $2(6.5 \%)$ & \\
\hline & 胃外科 & $4(12.9 \%)$ & \\
\hline & 大腸外科 & $4 \quad(12.9 \%)$ & \\
\hline & 泌尿器 - 後腹膜腫瘍科 & $1(3.2 \%)$ & \\
\hline & 皮膚腫瘍科 & $1(3.2 \%)$ & \\
\hline & 肝胆膵外科 & $2(6.5 \%)$ & \\
\hline & 頭頸部腫瘍科 & $1(3.2 \%)$ & \\
\hline & 婦人腫瘍科 & $1(3.2 \%)$ & \\
\hline & 脳脊䯣腫瘍科 & $2(6.5 \%)$ & \\
\hline & 放射線治療科 & $1(3.2 \%)$ & \\
\hline & 小児腫瘍科 & $1(3.2 \%)$ & \\
\hline \multicolumn{4}{|c|}{ 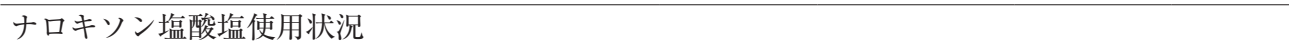 } \\
\hline \multirow[t]{3}{*}{ 使用理由 } & 呼吸抑制 & 8 & 1 \\
\hline & 覚醒遅延 & 4 & 0 \\
\hline & 不明 & 19 & 0 \\
\hline \multirow[t]{2}{*}{ 投与方法 } & 静注 / 持続 & $31 / 0$ & $1 / 0$ \\
\hline & 平均使用量 $(\mathrm{mg})$ & $0.19 \pm 0.16$ & 0.1 \\
\hline \multicolumn{4}{|c|}{ 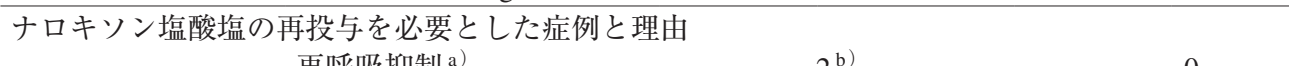 } \\
\hline
\end{tabular}




\section{I 群と I群のオピオイド使用状況}

I 群とII 群のオピオイド使用状況を表 3 に示す. 対象手術症例に対するモルヒネ塩酸塩使用割合は I 群 669/7,669 例（8.7\%), II 群 124/3,196 例（3.9\%） で有意に減少した $(P<0.001)$ ，モルヒネ塩酸塩の 平均使用量 (平均 \pm 標準偏差) は I 群 $25.82 \pm$ $28.21 \mu \mathrm{g} / \mathrm{min}$, II 群 $28.06 \pm 29.32 \mu \mathrm{g} / \mathrm{min}$ で不変で あった $(P=0.420)$. フェンタニルクエン酸塩使用 症例は I 群 6,221 例 (81.1\%), II 群 2,705 例 (84.6\%) で有意に増加した $(P<0.001)$ ）フェンタニルク エン酸塩の平均使用量は I 群 $2.18 \pm 1.8 \mu \mathrm{g} / \mathrm{min}$, II 群 $2.15 \pm 1.8 \mu \mathrm{g} / \mathrm{min}$ で不変であった $(P=0.476)$. レミフェンタニル塩酸塩使用症例は I 群 4,108 例 (53.6\%)，II 群 2,176 例（68.1\%）で有意に増加 した $(P<0.001)$ ，レミフェンタニル塩酸塩の平均 使用量は I 群 $11.34 \pm 8.34 \mu \mathrm{g} / \mathrm{min}, \quad$ II 群 $10.29 \pm$ $8.53 \mu \mathrm{g} / \mathrm{min}$ で, 有意に減少した $(P<0.001)$. なお, Fortec ORSYS ${ }^{\otimes}$ による情報からは硬膜外麻酔に使 用したオピオイド使用量は不明であったが，当院 のルールでは硬膜外麻酔に使用されるオピオイド はフェンタニル塩酸塩のみとなっている.

\section{5. ナロキソン塩酸塩使用症例のオピオイド使用 状況}

ナロキソン塩酸塩使用症例のオピオイド使用状
況を表 4 に示す．ナロキソン塩酸塩使用症例のう ち, モルヒネ塩酸塩使用症例は I 群 14 例, II 群 0 例であった. I 群のモルヒネ塩酸塩平均使用量 は $38.7 \pm 36.8 \mu \mathrm{g} / \mathrm{min}$ であった.ナロキソン塩酸 塩使用症例のうち, フェンタニルクエン酸塩使用 症例は I 群 18 例, II 群 1 例だった。フェンタニル クエン酸塩平均使用量は I 群が $2.5 \pm 1.7 \mu \mathrm{g} / \mathrm{min}$, II 群が $2.35 \mu \mathrm{g} / \mathrm{min}$ だった。ナロキソン塩酸塩使 用症例のうち，レミフェンタニル塩酸塩使用症例 は I 群 15 例，II 群 1 例だった.レミフェンタニ ル塩酸塩平均使用量は I 群が $12.1 \pm 7.8 \mu \mathrm{g} / \mathrm{min}$, II 群が $10.28 \mu \mathrm{g} / \mathrm{min}$ だった。

\section{6. その他の副作用と術中使用薬剤}

I 群, II 群における周術期の副作用と術中使用 薬棛を表 5 に示す. I 群, II 群の両群においてフ ルルビプロフェンの使用がみられた。またニカル ジピン塩酸塩とベラパミル塩酸塩の使用割合は I 群とII 群において増加は認めなかった。 症状の有 無についての記録では術後疼痛, 嘔気, 血圧の項 目において記載はなかったが，II群においては術 後疼痛 7 例, 嘔気 8 例の症状ありの記載があった.

表 3 オピオイド使用状況の比較

\begin{tabular}{|c|c|c|c|c|}
\hline & & $\begin{array}{c}\text { I 群 } \\
(\mathrm{n}=7669)\end{array}$ & $\begin{array}{c}\text { II 群 } \\
(\mathrm{n}=3196)\end{array}$ & $P$ 值 \\
\hline \multirow[t]{3}{*}{ 使用症例数 } & モルヒネ塩酸塩 & 669 & 124 & $<0.001$ \\
\hline & フェンタニルクエン酸塩 & 6,221 & 2,705 & $<0.001$ \\
\hline & レミフェンタニル塩酸塩 & 4,108 & 2,176 & $<0.001$ \\
\hline \multirow{3}{*}{$\begin{array}{l}\text { 使用量 } \\
\text { （ } \mu \mathrm{g} / \text { 手術時間：分） }\end{array}$} & モルヒネ塩酸塩 & $25.82 \pm 28.21$ & $28.06 \pm 29.32$ & 0.420 \\
\hline & フェンタニルクエン酸塩 & $2.18 \pm 1.8$ & $2.15 \pm 1.8$ & 0.476 \\
\hline & レミフェンタニル塩酸塩 & $11.34 \pm 8.34$ & $10.29 \pm 8.53$ & $<0.001$ \\
\hline
\end{tabular}

表 4 ナロキソン塩酸塩使用患者のオピオイド使用量

\begin{tabular}{|c|c|c|c|}
\hline & & I 群 & III 群 \\
\hline \multicolumn{2}{|c|}{ ナロキソン塩酸塩使用症例数 } & 31 & 1 \\
\hline \multirow[t]{3}{*}{ 使用症例数 } & モルヒネ塩酸塩 & 14 & 0 \\
\hline & フェンタニルクエン酸塩 & 18 & 1 \\
\hline & レミフェンタニル塩酸塩 & 15 & 1 \\
\hline 使用量 & モルヒネ塩酸塩 & $38.7 \pm 36.8$ & 0 \\
\hline \multirow[t]{2}{*}{ ( $\mu \mathrm{g} /$ 手術時間 : 分) } & フェンタニルクエン酸塩 & $2.5 \pm 1.7$ & 2.35 \\
\hline & レミフェンタニル塩酸塩 & $12.1 \pm 7.8$ & 10.28 \\
\hline
\end{tabular}


表 5 その他の副作用と術中使用薬

\begin{tabular}{|c|c|c|c|}
\hline & & $\begin{array}{c}\text { I 群 } \\
(\mathrm{n}=7,669)\end{array}$ & $\begin{array}{c}\text { II 群 } \\
(\mathrm{n}=3,196)\end{array}$ \\
\hline \multirow[t]{5}{*}{ 追加使用薬剤 } & アセトアミノフェン点滴静注 $1,000 \mathrm{mg}$ & 0 & 0 \\
\hline & フルルビプロフェン静注 50 mg & 2,660 & 1,235 \\
\hline & ニカルジピン塩酸塩静注 $10 \mathrm{mg}$ & 0 & 1 \\
\hline & ニカルジピン塩酸塩静注 2 mg & 241 & 7 \\
\hline & ベラパミル塩酸塩静注 $5 \mathrm{mg}$ & 5 & 1 \\
\hline \multirow[t]{3}{*}{ 有害事象（症状） } & 術後疼痛 & 異常の記載なし & 7 \\
\hline & 嘔気 & 異常の記載なし & 8 \\
\hline & 血圧 & 異常の記載なし & 異常の記載なし \\
\hline
\end{tabular}

\section{考察}

当院では, ナロキソン塩酸塩を必要とする可能 性の高い症例 ${ }^{4,9-11)}$ には速やかにナロキソン塩酸 塩が使用できる管理方法が必要と考え, ナロキソ ン塩酸塩の管理は取り出しが容易な通常の薬品棚 で行っていた。しかし，今回ナロキソン塩酸塩の 不適切な使用の可能性が指摘され，管理方法の見 直しを行った，その結果，ナロキソン塩酸塩の管 理方法変更後は不明瞭な理由によるナロキソン塩 酸塩の使用が減少した。

当院での管理方法変更前のナロキソン塩酸塩の 使用割合 $0.4 \%$ は, 2004 年のChshman らによる meta-analysis の報告 ${ }^{3)} 0.3 \%, 2015$ 年の Weingarten らの報告 ${ }^{4} 0.16 \%$ と比較し, 新規オピオイドであ るレミフェンタニルの使用が含まれていることを 考慮すると少なくはない，しかし，本研究におい ては年齢および術式以外の既往歴や術前呼吸器機 能など呼吸抑制のリスクとなる項目が調査されて いないためナロキソン塩酸塩の使用割合について は慎重に判断する必要がある。

管理方法変更後のナロキソン塩酸塩の使用症例 は 1 例だった。常駐薬剤師が麻酔医からの相談時 に処方を許可しなかった症例はなく，担当麻酔医 からの相談に対して上級麻酔医が許可しない症例 の有無については不明であった。

管理方法変更前での呼吸抑制以外のナロキソン 塩酸塩の使用理由は, 覚醒遅延 4 例と不明 19 例 (計 71\%）であった。 さらに，手術室でのナロキソン 塩酸塩の投与方法は全例単回使用で, 呼吸抑制で ナロキソン塩酸塩を使用した 8 例中 2 例はナロキ ソン塩酸塩初回投与後に再度呼吸抑制を起こして
いた．釘宮らは術中オピオイド使用症例に対する ナロキソン塩酸塩の効果と安全性についての報告 ${ }^{6}$ のなかで, ナロキソン塩酸塩使用 99 例中 14 症例 （14\%）において追加投与を行っており，ナロキ ソン塩酸塩投与後の厳重な監視の必要性について 注意喚起を行っている. 管理方法変更前のナロキ ソン塩酸塩使用症例において, ナロキソン塩酸塩 の効果が不十分な症例に対して適切なナロキソン 塩酸塩の追加投与が行われなかった可能性があ る. それに対して, 管理方法変更後のナロキソン 塩酸塩使用症例は 1 例で使用理由は呼吸抑制で あった，投与方法は単回投与であったが，慎重な モニタリングを継続し詳細が診療録に記録されて いたことからガイドラインの原則を遵守した対応 となっていたと考える.

また，ナロキソン塩酸塩の管理方法変更前後で モルヒネ塩酸塩の使用症例数が減少した。モルヒ ネ塩酸塩の使用量および投与方法（静注）は前後 で不変であったことより, 麻酔医がモルヒ市塩酸 塩を使用する症例をより厳選した可能性が示唆さ れる．このことは，フェンタニルクエン酸塩およ びレミフェンタニル塩酸塩の使用症例数が増加し ていることからも支持される.

管理方法を厳重にした影響により周術期の副作 用出現に影響がなかったか否かを調査する目的 で, 術中使用薬剤と副作用について調査した。使 用薬剤については I 群と比較して II 群の使用薬剤 の増加は認めなかった。また副作用については, 術後疼痛 7 例, 嘔気 8 例の記載以外の記載は認め ておらず，ナロキソン塩酸塩の管理方法変更によ る特記すべき有害事象はなかったと考える。

本研究の限界は, 後方視的調查でありバイアス, 
交絡の除去が不完全であったことが挙げられる. 麻酔薬掞よび麻酔関連薬使用ガイドラインでは, フェンタニルクエン酸塩は通常麻酔導入時に 2 $6 \mu \mathrm{g} / \mathrm{kg}$ を静注し，引き続き $1 \sim 2 \mu \mathrm{g} / \mathrm{kg}$ で持続静 注すると記載されている。モルヒネ塩酸塩は麻酔 薬として $0.1 〜 0.4 \mathrm{mg} / \mathrm{kg}$ を静注すると記載され ている，一般的にオピオイドは体重に応じて投与 量が決定されるが, 実臨床においては臟器機能な どに応じて麻酔医による用量調節が行われてい る. 本研究においても，オピオイド使用量は症例 毎の体重および手術時間での補正を計画したが Fortec ORSYS ${ }^{\otimes}$ からの体重デー夕の抽出が困難で あり，手術時間（分）あたりの使用量のみでの補 正となったため症例個人の厳密な使用量が算出で きなかった。しかし，対象症例における小児腫瘍 科の割合は $0.4 \%$ であることより結果に問題とな る影響はないものと考える。また術中使用薬剤と してファモチジン，メトクロプラミド，フロセミ ドの使用状況を調査したが，院内での取り扱い製 片が変更されたことや診療情報システムの変更な どからデー夕の抽出に問題点が多く指摘されたこ とから今回評価できなかった。

近年，手術室に薬剤師が配置される施設は増加 傾向であり，過去と比べょり適切な薬品管理が行 われつつある。しかし，薬剤師は薬の管理のみで はなく周術期に使用される薬剤の特性を把握し て, 自らの施設での薬剤の使用方法を監視し, 薬 の責任者として積極的に介入していく必要があ る. 今回のナロキソン塩酸塩の管理方法の変更は, 麻酔医のオピオイド適正使用を促し, さらにナロ キソン塩酸塩の使用を減少させた。これは管理方 法のみではなく, 薬剤師が症例毎に状態を把握し 投与方法に踏み达んだ成果であるとも考えられ る. 今回の研究において, ナロキソン塩酸塩の管 理方法の変更は有用であったと考える.

\section{利益相反}

開示すべき利益相反はない.

\section{引用文献}

1）高折修二, 福田英臣, 赤池明紀, 石井邦雄, “グッ ドマン・ギルマン薬理書”, 廣川書店, 東京, 2007, pp688-785.

2) Sauter K, Kaufman HH, Bloomfield SM, Cline S, Banks D, Treatment of high-dose intrathecal morphine overdose: Case report, J Neurosurg, 1994, 81, 143-146.

3) Cashman JN, Dolin SJ, Respiratory and haemodynamic effects of acute postoperative pain management: evidence from published data, Br J Anaesth, 2004, 93, 212-223.

4) Weingarten $T N$, Herasevich V, McGlinch MC, Beatty NC, Christensen ED, Hannifan SK, Koenig AE, Klanke J, Zhu X, Gali B, Schroeder DR, Sprung J, Predictors of delayed postoperative respiratory depression assessed from naloxone administration, Anesth Analg, 2015, 121, 422-429.

5）瀬戸口大典, 垣花泰之, ナロキソン（特集 拮抗作 用から見た麻酔関連薬物の最新知見), 麻酔, 2013, 62, 5-9.

6）釘宮豊城, 術中モルヒネおよびペンタゾシン投 与症例に対するナロキソン呼吸抑制拮抗効果に ついて一多施設共同臨床試験の報告, 麻酔, 1982, 31, 1365-1375.

7) Kosterlitz HW, Watt AJ, Kinetic parameters of narcotic agonists and antagonists, with particular reference to $\mathrm{N}$-allylnoroxymorphone (naloxone), Br J Pharmacol Chemother, 1968, 33, 266-276.

8) Ngai SH, Berkowitz BA, Yang JC, Hempstead J, Spector S, Pharmacokinetics of naloxone in rats and in man: basis for its potency and short duration of action, Anesthesiology, 1976, 44, 398-401.

9) Weingarten, TN, Chong EY, Schroeder DR, Sprung $\mathrm{J}$, Predictors and outcomes following naloxone administration during Phase I anesthesia recovery, J Anesth, 2016, 30, 116-122.

10) Gordon, DB, Pellino TA, Incidence and characteristics of naloxone use in postoperative pain management: a critical examination of naloxone use as a potential quality measure, Pain Manag Nurs, 2005, 6, 30-36.

11) Taylor S, Kirton OC, Staff I, Kozol RA, Postoperative day one: a high risk period for respiratory events, Am J Surg, 2005, 190, 752-756. 